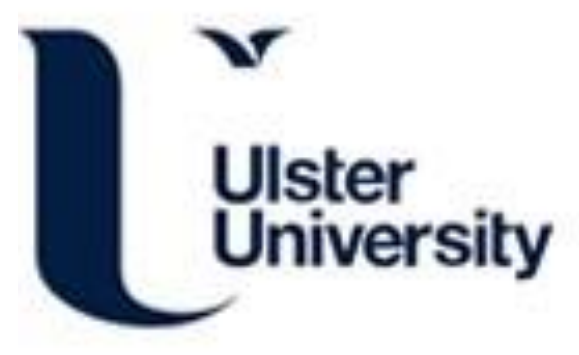

\title{
Combinational effect of angiotensin receptor blocker and folic acid therapy on uric acid and creatinine level in hyperhomocysteinemia-associated hypertension
}

Singh, Y., Samuel, V. P., Dahiya, S., Gupta, G., Gillhotra, R., Mishra, A., Singh, M., SreeHarsha, N.,

Gubbiyappa, S. K., Tambuwala, M. M., Chellappan, D. K., \& Dua, K. (2019). Combinational effect of angiotensin receptor blocker and folic acid therapy on uric acid and creatinine level in hyperhomocysteinemia-associated hypertension. Biotechnology and Applied Biochemistry, 66(5), 715-719. https://doi.org/10.1002/bab.1799

Link to publication record in Ulster University Research Portal

Published in:

Biotechnology and Applied Biochemistry

Publication Status:

Published (in print/issue): 01/09/2019

DOI:

10.1002/bab.1799

Document Version

Author Accepted version

\section{General rights}

Copyright for the publications made accessible via Ulster University's Research Portal is retained by the author(s) and / or other copyright owners and it is a condition of accessing these publications that users recognise and abide by the legal requirements associated with these rights.

\section{Take down policy}

The Research Portal is Ulster University's institutional repository that provides access to Ulster's research outputs. Every effort has been made to ensure that content in the Research Portal does not infringe any person's rights, or applicable UK laws. If you discover content in the Research Portal that you believe breaches copyright or violates any law, please contact pure-support@ulster.ac.uk. 


\title{
Combinational Effect of Angiotensin Receptor Blocker and Folic Acid Therapy on Uric
} Acid and Creatinine Level in Hyperhomocysteinemia Associated Hypertension
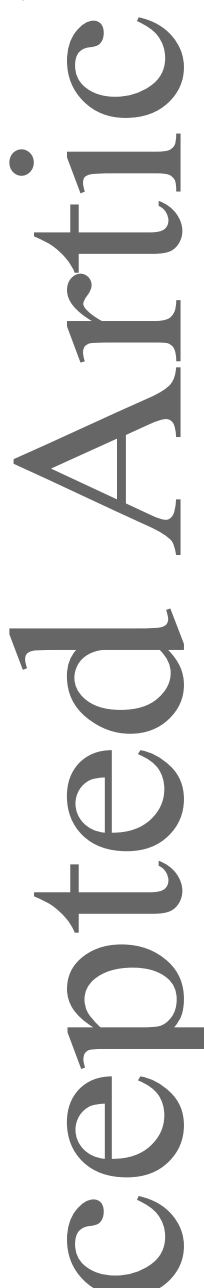

.

\author{
Yogendra Singh ${ }^{1}$, Vijaya Paul Samuel ${ }^{2}$, Sunita Dahiya ${ }^{3}$, Gaurav Gupta ${ }^{4}$, Ritu Gillhotra ${ }^{4}$, \\ Anurag Mishra ${ }^{4}$, Mahaveer Singh $^{5}$, Nagaraja SreeHarsha ${ }^{6}$, Shiva Kumar Gubbiyappa ${ }^{7}$, \\ Murtaza M. Tambuwala ${ }^{8}$, Dinesh Kumar Chellappan ${ }^{9}$, Kamal Dua ${ }^{10,11}$
}

1. Department of pharmaceutical sciences, Mahatma Gandhi College of Pharmaceutical Sciences, Sitapura, Jaipur, India

2. Department of Anatomy, RAK College of Medicine, RAK Medical and Health Sciences, University, Ras Al Khaimah, UAE

3. Department of Pharmaceutical Sciences, School of Pharmacy, University of Puerto Rico, Medical Sciences Campus, San Juan, Puerto Rico, USA

4. School of Pharmacy, Suresh Gyan Vihar University, Jagatpura, Mahal Road, Jaipur, India

5. School of Pharmaceutical Sciences, Jaipur National University, Jagatpura, Jaipur, India

6. Department of Pharmaceutical Sciences, College of Clinical Pharmacy, King Faisal University, Al-Ahsa, Saudi Arabia

7. School of Pharmacy, GITAM University, Hyderabad, India

8. School of Pharmacy \& Pharmaceutical Sciences, Ulster University, Coleraine, County Londonderry, Northern Ireland, United Kingdom

9. Department of Life Sciences, International Medical University, Kuala Lumpur, Malaysia 57000

10. Discipline of Pharmacy, Graduate School of Health, University of Technology Sydney, Sydney, NSW 2007, Australia

11. Priority Research Centre for Healthy Lungs, School of Biomedical Sciences and Pharmacy, The University of Newcastle, Callaghan, Australia

\section{Corresponding Author:}

This article has been accepted for publication and undergone full peer review but has not been through the copyediting, typesetting, pagination and proofreading process, which may lead to differences between this version and the Version of Record. Please cite this article as doi: $\underline{10.1002 / b a b .1799 .}$.

This article is protected by copyright. All rights reserved. 
1. Yogendra Singh, Department of pharmaceutical sciences, Mahatma Gandhi College of Pharmaceutical Sciences, Sitapura, Jaipur, India.

Email Id: yogendra.singh119@gmail.com

2. Gaurav Gupta, School of Pharmaceutical Sciences, Jaipur National University, Jagatpura 302017, Jaipur, India.

Email Id: gauravpharma25@gmail.com

\section{Abstract}

Homocysteine [HSCH2CH2CH(NH2)COOH] (Hcy), is a sulfur-containing amino acid of 135.18 Da of molecular weight, generated during conversion of methionine to cysteine. If there is a higher accumulation of Hcy in the blood, i.e. usually above $15 \mu \mathrm{mol} / \mathrm{L}$, it leads to a condition referred to as hyperhomocysteinemia. A meta-analysis of observational study suggested an elevated concentration of Hcy in blood, which is termed as the risk factors leading to ischemic heart disease (IHD) and stroke. Further experimental studies stated that Hcy can lead to an increase in the proliferation of vascular smooth muscle cells and functional impairment of endothelial cells. The analyses confirmed some of the predictors for Hcy presence, such as serum uric acid (UA), systolic blood pressure, and hematocrit. However, angiotensin-converting enzyme inhibitors Angiotensin-converting enzyme (ACE) inhibitors and angiotensin converting enzyme inhibitors (ARBs) (except losartan) alone are inadequate for controlling UA and creatinine level, although the addition of folic acid may be beneficial in hypertensive patients who are known to have a high prevalence of elevated Hcy. We hypothesized that combination therapy with an ARB (olmesartan) and folic acid is a 
promising treatment for lowering the UA and creatinine level in hyperhomocysteinemia associated hypertension.

Keywords: Homocysteine, hyperhomocysteinemia, hypertension, creatinine, angiotensin receptor blocker, folic acid

\section{Highlights}

1. Higher accumulation of Homocysteine in the blood leads to a hyperhomocysteinemia.

2. Folic acid is a good candidate as a supplement for treating the hyperhomocysteinemia associated hypertension.

3. Folic acid does not affect the function of normal cell.

\section{Introduction}

Hcy was identified in 1932 by Butz and du Vigneaud at the University of Illinois as an amino acid of biological importance [1]. Mudd et. al. in 1964 for the first time identified the enzyme defects in cystathionine $\beta$ synthase causing homocystinuria [2]. A study in 1969 stated the role played by a high level of Hcy in causing atherosclerosis through deposition of fibrin, oxidant stress, the release of cytokine, inflammation and other related mechanisms [3-5].

\section{Synthesis of Homocysteine}

In the synthesis of Hcy, methionine (has a methyl group attached with a sulfur atom) is converted to S-Adenosyl Methionine (SAMe), in the presence of methionine adenosyltransferase (MAT) and ATP with the addition of adenosine to the sulfur which activates the methyl group [6]. Removing the methyl group from SAMe leads to the formation of SAH (S-Adenosyl Hcy). Further, in the presence of a hydrolase enzyme, SAh is converted to Hcy by adenosine removal [7] (Figure 1).

\section{Metabolism of Homocysteine}


Metabolism of Hcy is carried out in three different ways:

1) In liver cells, the transsulfuration pathway is catalyzed by Vitamin B6, which leads to the conversion of Hcy (around 60\%) to cysteine (Cys). Cys can be used as building blocks for many proteins that can be used in the formation of glutathione (GSH), which is an anti-oxidant or oxidized to form the taurine (an amino acid) [8,9].

2) Hcy can also be reconverted to Met through the addition of a methyl group. The methyl group can be added in the presence of methionine synthase enzyme and vit. B12, where methylated folic acid (Methyltetrahydrofolate, MTHF) acts as the methyl group donor [10-13].

3) In another liver pathway, choline is converted to betaine (TMG), which acts as the methyl group donor $[14,15]$

The prevalence of hyperhomocysteinemia in India varies from $52 \%-84 \%$ which is caused due to elevated levels of Hyc $[16,17]$.In the case of fasting, the total plasma concentration of Hcy seemed to be low, i.e. 5-15 $\mu \mathrm{mol} / \mathrm{L}$ using HPLC techniques, in case of healthy humans. Application of immunoassay techniques for the determination of levels of Hcy yielded 5$12 \mu \mathrm{mol} / \mathrm{L}$ concentration [18]. A concentration level higher than $100 \mu \mathrm{mol} / \mathrm{L}$ leads to severe severe hyperhomocysteinemia, whereas $16-30 \mu \mathrm{mol} / \mathrm{L}$ of Hcy leads to moderate condition and a value between 31-100 $\mu \mathrm{mol} / \mathrm{L}$ leads to the intermediate condition [19-21].

Elevated Hcy levels are connected with various pathologies both in adults and children. Causes of high Hcy concentration include genetic mutations in 5, 10methylenetetrahydrofolate reductase (MTHFR) and enzyme deficiencies of methionine synthase (MS) and cystathionine $\beta$-synthase (CßS) (21-23). 


\section{Homocysteine Associated cardiovascular problem}

All forms of hypertension related to high systolic and diastolic pressure as well as high pulse pressure, have been treated as recognizable and independent risk factors for determination of cardiovascular morbidity and mortality. For reducing such risk factors, anti-hypertensive treatment needs to be adopted that uses anti-hypersensitive agents, alone or in combination [22]. Furthermore, Hyc as an independent risk factor leading to cardiovascular modalities, due to the increase in the oxidative stress [23-25].

Some of the population-based studies have stated a direct interlinking between the levels of Hcy with blood pressure, especially systolic. A previous study stated that the increase in plasma Hcy concentration by $5 \mu \mathrm{mol} / \mathrm{L}$ leads to an increase in the blood pressure by $0.7 / 0.5$ $\mathrm{mmHg}$ and 1.2/0.7 $\mathrm{mmHg}$, in men and women, respectively. A meta-analysis study in an observational study suggested that an elevated level of total blood Hyc concentrations are associated with the risk of IHD and stroke [26-28]. With every $3 \mu \mathrm{mol} / \mathrm{L}$ elevation in the level of Hcy, the risk of IHD increased by around $11 \%$ and that of stroke increased by around $19 \%[29]$.

\section{Arteriolar constriction}

The structure, as well as functionality of arteries, are affected by high levels of Hcy. As mentioned earlier, the proliferation of vascular smooth muscle cell and impairment of endothelial function can be an after-effect of increased Hcy concentration [30, 31], thus leading to increased arteriolar constriction as well as peripheral resistance. It may also lead to an increase in the blood pressure by elevating the total peripheral resistance, especially by small resistant arterioles and arteries [32-34].

\section{Insulin Resistance:}


The increased resistance of insulin (hyperinsulinemia) associated with clinical manifestation of hyperhomocysteinemia elevated blood pressure. The condition of hyperinsulinemia may lead to an increase in the level of Hcy as well as elevate blood pressure through various mechanisms. On the contrary, factors like dietary habits also contribute to insulin resistance [35-37]. In summary, metabolic disturbances and long-term hyperhomocysteinemia together with vascular remodeling suggested that enhanced oxidative stress, endothelium dysfunction, and decreased PPAR $\gamma$ expression in the vessel wall could be underlying mechanisms for hyperhomocysteinemia associated hypertension [38].

\section{Hyperuricemia and creatinine}

Hyperuricemia leads to urate crystal deposition in between the joints, thus becoming a prime risk factor in the development of gout [39]. In addition to this, it also leads to other clinical diseases, such as cardiovascular and cerebrovascular conditions. Elevated concentration of UA is linked to increased rates of cardiovascular (CV) morbidity and mortality, stroke, chronic kidney disease, metabolic syndrome, and hypertension in the general population [4049]. Multivariate analysis study was conducted to detect that systolic blood pressure, UA, and hematocrit are the predictors for increased Hcy concentration, [50-52]. Moreover, the various study explores significant correlations between Hcy, uric acid, and creatinine [53, 54].

\section{Arrhythmias}

Slightly enhance the micromolar concentration of Hcy between 50-500 micromole/Liter in the blood leads to inhibition of cardiac $\mathrm{Na}^{+}$and $\mathrm{K}^{+}$channels and transient outward current which prolongs the action potential and change in electrophysiologic properties of the heart [55-57].

\section{Effect of ACE inhibitors and ARBs in hyperhomocysteinemia associated hypertension}


The vasodilatory property of RAAS inhibitor candidates, like ACE inhibitors and ARBs and have found to reduce the risk of CV disease via oxidative stress management [58]. However, ACEIs drugs like enalapril have been found to be non-effective in controlling the blood pressure in the presence of Hcy $\geq 15 \mu \mathrm{mol} / \mathrm{L}$ [59-61]. On the other hand, a randomized study on ACE inhibitor like captopril has statistically insignificant effects on tHcy after 4 weeks or creatinine [62] while Enalapril may also increase in plasma tHcy among the hypertensive patients[63]. Moreover, the treatment group receiving enalapril significantly increase the serum uric acid concentration and [64] which is an independent risk factor for oxidative stress, stroke/ transient ischemic attack at the value $\geq 6.35 \mathrm{mg} / \mathrm{dl}[65]$. However, ACEIs inhibit the synthesis of biologically active peptide Angiotensin II by blocking the ACE but the synthesis of AngII resumed due to activation of a non-ACE pathway that will be mediated in the presence of chymase, kallikrein, cathepsin $G$, and elastase-2 enzyme[66]. Hence, the oxidative stress is enhanced by activation of the AT1 receptor [67-69].

A recent animal study shows that mild to moderate increase in Hcy concentration leads to increase expression and binding and of AT1 Receptor that mediated vascular injury [70, 71]. A previous study showed no significant change in the levels of plasma Hcy in hypertensive patients administered with Olmesartan [72-74]. However, when these patients were treated with either candesartan or amlodipine, at least $2 \mu \mathrm{mol}^{-1}$ increase in Hcy concentration was observed in the study patients [75-77]. Moreover, ARBs increase the level of serum creatinine and uric acid (except Losartan) because losartan inhibits URAT1, a major transporter in the kidney for uric acid reabsorption while other ARBs does not do it at therapeutic concentration [78-84].

\section{Folic acid}


Folate is an essential element required in synthesis of pyrimidine, purine (precursors of DNA and RNA, respectively) and amino acid metabolism including Hcy. Deficiency of folate results in increasing the risk of getting hyperhomocysteinemia $[85,86]$.

However, ACE inhibitors and ARBs (except losartan) alone are inadequate for controlling UA and creatinine level, although the addition of folic acid may be beneficial, in hypertensive patients who are known to have a high prevalence of elevated homocysteine (Hcy)[87-90]. Conventional hyper uric acid therapies aim at either reducing UA production using xanthine oxidase (XO) inhibitors, such as allopurinol, or increasing renal UA excretion with drugs, such as benzene bromide malone and probenecid. However, these agents can effectively lower the serum UA levels but they do have a number of side effects, including allergic reactions, liver damage, kidney damage, bone marrow suppression and gastrointestinal symptoms [91-93]. Thus, we need safe and effective therapeutic approaches. Hence fore, Folic acid is several folds more potent as an inhibitor of Xanthine oxidase than the know inhibitor allopurinol, which results decrease the level of uric acid [94, 95].

\section{Conclusion:}

In the clinical setting, RAAS inhibitor is the first choice of drug for the treatment of hypertension by medical practitioners but the determination of homocysteine level is not very frequent for diagnosis of hypertension in adults and geriatric patients that may arise certain blood pressure related consequences. So, folic acid could be a good candidate as a supplement for treating the hyperhomocysteinemia associated hypertension. Moreover, folic acid does not affect the function of normal cell i.e could be used as nutrients and growth supplement for damage cell due to oxidative stress. 
Most of the previous studies also demonstrated that use of folic acid ( $0.4 \mathrm{mg} /$ day $)$ supplementation failed to lower blood Hcy, uric acid and creatinine level, while high dose $1000 \mathrm{mg}$ does not significantly lower the uric acid concentration. Contradictions in the study outcomes might be due to small sample size and differences in population characteristics, for example, patients treated with or without folate supplementation.

Thus, as a future perspective, we need to establish an adequate dose of folic acid as a supplement with ARB like Olmesartan for the treatment of hyperhomocysteinemia associated hypertension.

\section{Funding acknowledgment}

This review was self-funded.

\section{Conflict of interest}

Authors declare no conflict of interest

\section{References}

[1] Lewis W. Butz, V. d. V. (1932) THE FORMATION OF A HOMOLOGUE OF CYSTINE BY THE DECOMPOSITION OF METHIONINE WITH SULFURIC ACID. journal of biological chemistry 99, 135-142.

[2] Mudd, S. H., Finkelstein, J. D., Irreverre, F., Laster, L. (1964) HOMOCYSTINURIA: AN ENZYMATIC DEFECT. Science (New York, N.Y.) 143, 1443-1445.

[3] McCully, K. S. (1969) Vascular pathology of homocysteinemia: implications for the pathogenesis of arteriosclerosis. The American journal of pathology 56, 111-128.

[4] McCully, K. S. (2004) Homocysteine, vitamins, and prevention of vascular disease. Military medicine 169, 325-329.

[5] McCully, K. S. (2007) Homocysteine, vitamins, and vascular disease prevention. The American journal of clinical nutrition 86, 1563s-1568s.

[6] Mudd, S. H., Cantoni, G. L. (1958) Activation of methionine for transmethylation. III. The methionine-activating enzyme of Bakers' yeast. The Journal of biological chemistry 231, 481-492.

[7] Blom, H. J., Smulders, Y. (2011) Overview of homocysteine and folate metabolism. With special references to cardiovascular disease and neural tube defects. Journal of Inherited Metabolic Disease 34, 75-81.

[8] Quere, I., Paul, V., Rouillac, C., Janbon, C., London, J., Demaille, J., Kamoun, P., Dufier, J. L., Abitbol, M., Chasse, J. F. (1999) Spatial and temporal expression of the cystathionine beta-synthase 
gene during early human development. Biochemical and biophysical research communications 254, 127-137.

[9] Selhub, J. (1999) Homocysteine metabolism. Annual review of nutrition 19, 217-246.

[10] Li, Y. N., Gulati, S., Baker, P. J., Brody, L. C., Banerjee, R., Kruger, W. D. (1996) Cloning, mapping and RNA analysis of the human methionine synthase gene. Human molecular genetics $\mathbf{5}$, 1851-1858.

[11] Qiu, A., Jansen, M., Sakaris, A., Min, S. H., Chattopadhyay, S., Tsai, E., Sandoval, C., Zhao, R., Akabas, M. H., Goldman, I. D. (2006) Identification of an intestinal folate transporter and the molecular basis for hereditary folate malabsorption. Cell 127, 917-928.

[12] Leclerc, D., Wilson, A., Dumas, R., Gafuik, C., Song, D., Watkins, D., Heng, H. H., Rommens, J. M., Scherer, S. W., Rosenblatt, D. S., Gravel, R. A. (1998) Cloning and mapping of a cDNA for methionine synthase reductase, a flavoprotein defective in patients with homocystinuria.

Proceedings of the National Academy of Sciences of the United States of America 95, 3059-3064.

[13] Szulmajster, J., Woods, D. D. (1960) The synthesis of methionine from homocysteine by enzymic extracts of Escherichia coli. Biochemical Journal 75, 3-12.

[14] Sunden, S. L., Renduchintala, M. S., Park, E. I., Miklasz, S. D., Garrow, T. A. (1997) Betainehomocysteine methyltransferase expression in porcine and human tissues and chromosomal localization of the human gene. Archives of biochemistry and biophysics 345, 171-174.

[15] Finkelstein, J. D. (1998) The metabolism of homocysteine: pathways and regulation. European journal of pediatrics 157 Suppl 2, S40-44.

[16] Wadia, R. S., Edul, N. C., Bhagat, S., Bandishti, S., Kulkarni, R., Sontakke, S., Barhadi, S., Shah, M. (2004) Hyperhomocysteinaemia And Vitamin B12 Deficiency In Ischaemic Strokes In India. Annals of Indian Academy of Neurology 7, 387-392.

[17] Raut, M., Maheshwari, A. (2017) Hyperhomocysteinemia and left ventricular thrombus. Annals of Cardiac Anaesthesia 20, 276-277.

[18] Baszczuk, A., Kopczynski, Z. (2014) [Hyperhomocysteinemia in patients with cardiovascular disease]. Postepy higieny i medycyny doswiadczalnej (Online) 68, 579-589.

[19] Hankey, G. J., Eikelboom, J. W. (1999) Homocysteine and vascular disease. Lancet (London, England) 354, 407-413.

[20] Afzal, M., Gupta, G., Kazmi, I., Rahman, M., Afzal, O., Alam, J., Hakeem, K. R., Pravez, M., Gupta, R., Anwar, F. (2012) Anti-inflammatory and analgesic potential of a novel steroidal derivative from Bryophyllum pinnatum. Fitoterapia 83, 853-858.

[21] Wang, B., Gupta, G., Singh, M., Veerabhadrappa, K. V. S., Mishra, A., Chinnaboina, G. K. (2018) Pharmacological evaluation of novel flavone from Morus alba in Pentylenetetrazole-induced kindling and oxidative stress. Journal of Environmental Pathology, Toxicology and Oncology 37.

[22] Staessen, J. A., Wang, J. G., Thijs, L. (2001) Cardiovascular protection and blood pressure reduction: a meta-analysis. Lancet (London, England) 358, 1305-1315.

[23] Jonasson, T., Ohlin, A. K., Gottsater, A., Hultberg, B., Ohlin, H. (2005) Plasma homocysteine and markers for oxidative stress and inflammation in patients with coronary artery disease--a prospective randomized study of vitamin supplementation. Clinical chemistry and laboratory medicine 43, 628-634.

[24] Ahmad, A., Gupta, G., Afzal, M., Kazmi, I., Anwar, F. (2013) Antiulcer and antioxidant activities of a new steroid from Morus alba. Life sciences 92, 202-210.

[25] Sunkara, K. P., Gupta, G., Hansbro, P. M., Dua, K., Bebawy, M. (2018) Functional relevance of SATB1 in immune regulation and tumorigenesis. Biomedicine \& Pharmacotherapy 104, 87-93.

[26] Homocysteine Studies, C. (2002) Homocysteine and risk of ischemic heart disease and stroke: A meta-analysis. JAMA 288, 2015-2022.

[27] Chellappan, D. K., Ng, Z. Y., Wong, J.-Y., Hsu, A., Wark, P., Hansbro, N., Taylor, J., Panneerselvam, J., Madheswaran, T., Gupta, G., (2018) Immunological axis of curcumin-loaded vesicular drug delivery systems, Future Science.

This article is protected by copyright. All rights reserved. 
[28] Singh, Y., Gupta, G., Shrivastava, B., Dahiya, R., Tiwari, J., Ashwathanarayana, M., Sharma, R. K., Agrawal, M., Mishra, A., Dua, K. (2017) Calcitonin gene-related peptide (CGRP): A novel target for Alzheimer's disease. CNS neuroscience \& therapeutics 23, 457-461.

[29] (2002) Homocysteine and risk of ischemic heart disease and stroke: a meta-analysis. Jama 288, 2015-2022.

[30] van Guldener, C., Nanayakkara, P. W., Stehouwer, C. D. (2003) Homocysteine and blood pressure. Current hypertension reports 5, 26-31.

[31] van Guldener, C., Stehouwer, C. D. (2000) Hyperhomocysteinemia, vascular pathology, and endothelial dysfunction. Seminars in thrombosis and hemostasis 26, 281-289.

[32] Stehouwer, C. D., van Guldener, C. (2003) Does homocysteine cause hypertension? Clinical chemistry and laboratory medicine 41, 1408-1411.

[33] Dua, K., Bebawy, M., Awasthi, R., Tekade, R. K., Tekade, M., Gupta, G., De Jesus, A. P., Hansbro, P. M. (2017) Application of chitosan and its derivatives in nanocarrier based pulmonary drug delivery systems. Pharmaceutical nanotechnology 5, 243-249.

[34] Singh, Y., Gupta, G., Sharma, R., Matta, Y., Mishra, A., Pinto, T. d. J. A., Dua, K. (2018) Embarking Effect of ACE2-Angiotensin 1-7/Mas Receptor Axis in Benign Prostate Hyperplasia. Critical Reviews $^{\text {TM }}$ in Eukaryotic Gene Expression 28.

[35] Zhang, Y., Wang, G., Liu, J., Xu, Y. (2018) Impact of hyperhomocysteinemia on insulin resistance in patients with $\mathrm{H}$-type hypertension. Clinical and experimental hypertension (New York, N.Y. : 1993) 40, 28-31.

[36] Dua, K., Chakravarthi, S., Kumar, D., Sheshala, R., Gupta, G. (2013) Formulation, characterization, in vitro, in vivo, and histopathological evaluation of transdermal drug delivery containing norfloxacin and Curcuma longa. International journal of pharmaceutical investigation 3, 183.

[37] Sharma, S., Pathak, S., Gupta, G., Sharma, S. K., Singh, L., Sharma, R. K., Mishra, A., Dua, K. (2017) Pharmacological evaluation of aqueous extract of syzigium cumini for its antihyperglycemic and antidyslipidemic properties in diabetic rats fed a high cholesterol diet-Role of PPAR $y$ and PPARa. Biomedicine \& Pharmacotherapy 89, 447-453.

[38] Huo, Y., Wu, X., Ding, J., Geng, Y., Qiao, W., Ge, A., Guo, C., Lv, J., Bao, H., Fan, W. (2018) Vascular Remodeling, Oxidative Stress, and Disrupted PPARgamma Expression in Rats of Long-Term Hyperhomocysteinemia with Metabolic Disturbance. PPAR research 2018, 6738703.

[39] Zhang, W., Doherty, M., Pascual, E., Bardin, T., Barskova, V., Conaghan, P., Gerster, J., Jacobs, J., Leeb, B., Liote, F., McCarthy, G., Netter, P., Nuki, G., Perez-Ruiz, F., Pignone, A., Pimentao, J., Punzi, L., Roddy, E., Uhlig, T., Zimmermann-Gorska, I. (2006) EULAR evidence based recommendations for gout. Part I: Diagnosis. Report of a task force of the Standing Committee for International Clinical Studies Including Therapeutics (ESCISIT). Annals of the rheumatic diseases 65, 1301-1311.

[40] Iseki, K., Ikemiya, Y., Inoue, T., Iseki, C., Kinjo, K., Takishita, S. (2004) Significance of hyperuricemia as a risk factor for developing ESRD in a screened cohort. American journal of kidney diseases : the official journal of the National Kidney Foundation 44, 642-650.

[41] Feig, D. I., Soletsky, B., Johnson, R. J. (2008) Effect of allopurinol on blood pressure of adolescents with newly diagnosed essential hypertension: a randomized trial. Jama 300, 924-932.

[42] Strasak, A., Ruttmann, E., Brant, L., Kelleher, C., Klenk, J., Concin, H., Diem, G., Pfeiffer, K., Ulmer, H. (2008) Serum uric acid and risk of cardiovascular mortality: a prospective long-term study of 83,683 Austrian men. Clinical chemistry 54, 273-284.

[43] Nakagawa, T., Hu, H., Zharikov, S., Tuttle, K. R., Short, R. A., Glushakova, O., Ouyang, X., Feig, D. I., Block, E. R., Herrera-Acosta, J., Patel, J. M., Johnson, R. J. (2006) A causal role for uric acid in fructose-induced metabolic syndrome. American journal of physiology. Renal physiology 290, F625631.

This article is protected by copyright. All rights reserved. 
[44] Jimenez, M. C., Curhan, G. C., Choi, H. K., Forman, J. P., Rexrode, K. M. (2016) Plasma uric acid concentrations and risk of ischaemic stroke in women. European journal of neurology 23, 11581164.

[45] Grayson, P. C., Kim, S. Y., LaValley, M., Choi, H. K. (2011) Hyperuricemia and incident hypertension: a systematic review and meta-analysis. Arthritis care \& research 63, 102-110.

[46] Lv, Q., Meng, X. F., He, F. F., Chen, S., Su, H., Xiong, J., Gao, P., Tian, X. J., Liu, J. S., Zhu, Z. H., Huang, K., Zhang, C. (2013) High serum uric acid and increased risk of type 2 diabetes: a systemic review and meta-analysis of prospective cohort studies. PloS one 8, e56864.

[47] Bose, B., Badve, S. V., Hiremath, S. S., Boudville, N., Brown, F. G., Cass, A., de Zoysa, J. R., Fassett, R. G., Faull, R., Harris, D. C., Hawley, C. M., Kanellis, J., Palmer, S. C., Perkovic, V., Pascoe, E. M., Rangan, G. K., Walker, R. J., Walters, G., Johnson, D. W. (2014) Effects of uric acid-lowering therapy on renal outcomes: a systematic review and meta-analysis. Nephrology, dialysis,

transplantation : official publication of the European Dialysis and Transplant Association - European Renal Association 29, 406-413.

[48] Li, M., Hou, W., Zhang, X., Hu, L., Tang, Z. (2014) Hyperuricemia and risk of stroke: a systematic review and meta-analysis of prospective studies. Atherosclerosis 232, 265-270.

[49] Puddu, P., Puddu, G. M., Cravero, E., Vizioli, L., Muscari, A. (2012) Relationships among hyperuricemia, endothelial dysfunction and cardiovascular disease: molecular mechanisms and clinical implications. Journal of cardiology 59, 235-242.

[50] Malinow, M. R., Levenson, J., Giral, P., Nieto, F. J., Razavian, M., Segond, P., Simon, A. (1995) Role of blood pressure, uric acid, and hemorheological parameters on plasma homocyst(e)ine concentration. Atherosclerosis 114, 175-183.

[51] Dua, K., Malipeddi, V. R., Madan, J., Gupta, G., Chakravarthi, S., Awasthi, R., Kikuchi, I. S., De Jesus Andreoli Pinto, T. (2016) Norfloxacin and metronidazole topical formulations for effective treatment of bacterial infections and burn wounds. Interventional Medicine and Applied Science 8, 68-76.

[52] Sharma, G. N., Gupta, G., Sharma, P. (2018) A comprehensive review of free radicals, antioxidants, and their relationship with human ailments. Critical Reviews ${ }^{T M}$ in Eukaryotic Gene Expression 28.

[53] Lussier-Cacan, S., Xhignesse, M., Piolot, A., Selhub, J., Davignon, J., Genest, J., Jr. (1996) Plasma total homocysteine in healthy subjects: sex-specific relation with biological traits. The American journal of clinical nutrition 64, 587-593.

[54] Cohen, E., Levi, A., Vecht-Lifshitz, S. E., Goldberg, E., Garty, M., Krause, I. (2015) Assessment of a possible link between hyperhomocysteinemia and hyperuricemia. Journal of investigative medicine : the official publication of the American Federation for Clinical Research 63, 534-538.

[55] Pacher, P., Ungvari, Z., Kecskemeti, V. (1999) Electrophysiological effects of homocysteine in isolated rat right ventricular papillary muscles and left atria. General pharmacology 32, 439-443.

[56] Shontz, R. D., Xu, Z., Patel, K. P., Rozanski, G. J. (2001) Inhibition of K+ currents by homocysteine in rat ventricular myocytes. Journal of cardiovascular electrophysiology 12, 175-182.

[57] Cai, B. Z., Gong, D. M., Liu, Y., Pan, Z. W., Xu, C. Q., Bai, Y. L., Qiao, G. F., Lu, Y. J., Yang, B. F. (2007) HOMOCYSTEINE INHIBITS POTASSIUM CHANNELS IN HUMAN ATRIAL MYOCYTES. Clinical and Experimental Pharmacology and Physiology 34, 851-855.

[58] James, P. A., Oparil, S., Carter, B. L., et al. (2014) 2014 evidence-based guideline for the management of high blood pressure in adults: Report from the panel members appointed to the eighth joint national committee (jnc 8). JAMA 311, 507-520.

[59] Qin, X., Li, Y., Sun, N., Wang, H., Zhang, Y., Wang, J., Li, J., Xu, X., Liang, M., Nie, J., Wang, B., Cheng, X., Li, N., Sun, Y., Zhao, L., Wang, X., Hou, F. F., Huo, Y. (2017) Elevated Homocysteine Concentrations Decrease the Antihypertensive Effect of Angiotensin-Converting Enzyme Inhibitors in Hypertensive Patients. Arteriosclerosis, thrombosis, and vascular biology 37, 166-172.

[60] Dua, K., Rapalli, V. K., Shukla, S. D., Singhvi, G., Shastri, M. D., Chellappan, D. K., Satija, S., Mehta, M., Gulati, M., Pinto, T. D. J. A. (2018) Multi-drug resistant Mycobacterium tuberculosis \&

This article is protected by copyright. All rights reserved. 
oxidative stress complexity: Emerging need for novel drug delivery approaches. Biomedicine \& Pharmacotherapy 107, 1218-1229.

[61] Sah, S. K., Samuel, V. P., Dahiya, S., Singh, Y., Gilhotra, R. M., Gupta, G., Mishra, A., Sharma, R. K., Kumar, G. S., SreeHarsha, N. (2019) A contemporary biological pathway of islet amyloid polypeptide for the management of diabetic dementia. Chemico-biological interactions.

[62] Westphal, S., Rading, A., Luley, C., Dierkes, J. (2003) Antihypertensive treatment and homocysteine concentrations. Metabolism: clinical and experimental 52, 261-263.

[63] Fan, F. F., Huo, Y., Wang, X., Xu, X., Wang, B. Y., Xu, X. P., Li, J. P. (2010) Effect of enalapril on plasma homocysteine levels in patients with essential hypertension. Journal of Zhejiang University. Science. B 11, 583-591.

[64] Schmidt, A., Gruber, U., Böhmig, G., Köller, E., Mayer, G. (2001) The effect of ACE inhibitor and angiotensin II receptor antagonist therapy on serum uric acid levels and potassium homeostasis in hypertensive renal transplant recipients treated with CsA. Nephrology Dialysis Transplantation 16, 1034-1037.

[65] Bayar, N., Küçükseymen, S., Güven, R., Erkal, Z., Köklü, E., Yüksel, i. Ö., Çağırcı, G., Arslan, Ş. (2017) Association between serum uric acid and ischemic stroke in patients with nonvalvular paroxysmal atrial fibrillation. International Journal of the Cardiovascular Academy 3, 118-121.

[66] Uehara, Y., Miura, S., Yahiro, E., Saku, K. (2013) Non-ACE pathway-induced angiotensin II production. Current pharmaceutical design 19, 3054-3059.

[67] Jorde, U. P., Ennezat, P. V., Lisker, J., Suryadevara, V., Infeld, J., Cukon, S., Hammer, A., Sonnenblick, E. H., Le Jemtel, T. H. (2000) Maximally recommended doses of angiotensin-converting enzyme (ACE) inhibitors do not completely prevent ACE-mediated formation of angiotensin II in chronic heart failure. Circulation 101, 844-846.

[68] Gupta, G., Bebawy, M., Pinto, T. d. J. A., Chellappan, D. K., Mishra, A., Dua, K. (2018) Role of the tristetraprolin (zinc finger protein 36 homolog) gene in cancer. Critical Reviews ${ }^{T M}$ in Eukaryotic Gene Expression 28.

[69] K Chellappan, D., Ganasen, S., Batumalai, S., Candasamy, M., Krishnappa, P., Dua, K., Chellian, J., Gupta, G. (2016) The protective action of the aqueous extract of Auricularia polytricha in paracetamol induced hepatotoxicity in rats. Recent patents on drug delivery \& formulation 10, 72-76. [70] Li, T., Yu, B., Liu, Z., Li, J., Ma, M., Wang, Y., Zhu, M., Yin, H., Wang, X., Fu, Y., Yu, F., Wang, X., Fang, X., Sun, J., Kong, W. (2018) Homocysteine directly interacts and activates the angiotensin II type I receptor to aggravate vascular injury. Nature Communications $\mathbf{9}, 11$.

[71] Zhan, X. L., Yang, X. H., Gu, Y. H., Guo, L. L., Jin, H. M. (2018) Epigallocatechin gallate protects against homocysteine-induced vascular smooth muscle cell proliferation. Molecular and cellular biochemistry 439, 131-140.

[72] Jaén Águila, F., Mediavilla García, J., Esteva Fernández, D., Ramos Cortes, J., Fernández Torres, C., Jiménez Alonso, J. (2010) CHANGES OF VASCULAR INFLAMMATORY MARKERS IN A GROUP OF PATIENTS AFTER 16 WEEKS OF ANTIHYPERTENSIVE TREATMENT: PP.33.326. Journal of hypertension 28, e547-e548.

[73] Gupta, G., Chellappan, D. K., Kikuchi, I. S., Pinto, T. d. J. A., Pabreja, K., Agrawal, M., Singh, Y., Tiwari, J., Dua, K. (2017) Nephrotoxicity in rats exposed to paracetamol: the protective role of moralbosteroid, a steroidal glycoside. Journal of Environmental Pathology, Toxicology and Oncology 36.

[74] Hatware, K. V., Sharma, S., Patil, K., Shete, M., Karri, S., Gupta, G. (2018) Evidence for gastroprotective, anti-inflammatory and antioxidant potential of methanolic extract of Cordia dichotoma leaves on indomethacin and stress induced gastric lesions in Wistar rats. Biomedicine \& Pharmacotherapy 103, 317-325.

[75] Muda, P., Kampus, P., Zilmer, M., Ristimae, T., Fischer, K., Zilmer, K., Kairane, C., Teesalu, R. (2005) Effect of antihypertensive treatment with candesartan or amlodipine on glutathione and its redox status, homocysteine and vitamin concentrations in patients with essential hypertension.

Journal of hypertension 23, 105-112.

This article is protected by copyright. All rights reserved. 
[76] Gupta, G., Kazmi, I., Afzal, M., Rahman, M., Saleem, S., Ashraf, M. S., Khusroo, M. J., Nazeer, K., Ahmed, S., Mujeeb, M. (2012) Sedative, antiepileptic and antipsychotic effects of Viscum album L.(Loranthaceae) in mice and rats. Journal of ethnopharmacology 141, 810-816.

[77] Gupta, G., Tiwari, J., Dahiya, R., Sharma, R. K., Mishra, A., Dua, K. (2018) Recent updates on neuropharmacological effects of luteolin. EXCLI journal.

[78] Iwanaga, T., Sato, M., Maeda, T., Ogihara, T., Tamai, I. (2007) Concentration-dependent mode of interaction of angiotensin II receptor blockers with uric acid transporter. The Journal of pharmacology and experimental therapeutics 320, 211-217.

[79] Manolis, A. J., Grossman, E., Jelakovic, B., Jacovides, A., Bernhardi, D. C., Cabrera, W. J., Watanabe, L. A., Barragan, J., Matadamas, N., Mendiola, A., Woo, K. S., Zhu, J. R., Mejia, A. D., Bunt, T., Dumortier, T., Smith, R. D. (2000) Effects of losartan and candesartan monotherapy and losartan/hydrochlorothiazide combination therapy in patients with mild to moderate hypertension. Losartan Trial Investigators. Clinical therapeutics 22, 1186-1203.

[80] Nishida, Y., Takahashi, Y., Susa, N., Kanou, N., Nakayama, T., Asai, S. (2013) Comparative effect of angiotensin II type I receptor blockers on serum uric acid in hypertensive patients with type 2 diabetes mellitus: a retrospective observational study. Cardiovascular Diabetology 12, 159.

[81] Koc, Y., Mazi, E., Sakaci, T., Basturk, T., Damar, A. B., Ahbap, E., Unsal, A., Borlu, F. (2011) Effect of Olmesartan on serum cystatin C levels in the patients with essential hypertension. European review for medical and pharmacological sciences 15, 1389-1394.

[82] Bavbek, N., Kasapoglu, B., Isik, A., Kargili, A., Kirbas, I., Akcay, A. (2010) Olmesartan associated with acute renal failure in a patient with bilateral renal artery stenosis. Renal failure 32, 1115-1117.

[83] Schmidt, M., Mansfield, K. E., Bhaskaran, K., Nitsch, D., Sorensen, H. T., Smeeth, L., Tomlinson, L. A. (2017) Serum creatinine elevation after renin-angiotensin system blockade and long term cardiorenal risks: cohort study. BMJ (Clinical research ed.) 356, j791.

[84] Lockhart, B. E., Vencill, J. R., Felix, C. M., Johnson, D. A. (2005) Recombinant human mast-cell chymase: an improved procedure for expression in Pichia pastoris and purification of the highly active enzyme. Biotechnology and applied biochemistry 41, 89-95.

[85] Lucock, M. (2000) Folic acid: nutritional biochemistry, molecular biology, and role in disease processes. Molecular genetics and metabolism 71, 121-138.

[86] Wu, G., Fan, X., Wu, H., Liu, N., Li, X., Gou, L., Nie, Y., Zhao, R., Xi, T. (2010) Bioscreening of phage display antibody library and expression of a humanized single-chain variable fragment antibody against human connective tissue growth factor (CTGF/CCN2). Biotechnology and applied biochemistry 56, 95-102.

[87] Rayner, B. L., Trinder, Y. A., Baines, D., Isaacs, S., Opie, L. H. (2006) Effect of losartan versus candesartan on uric acid, renal function, and fibrinogen in patients with hypertension and hyperuricemia associated with diuretics. American journal of hypertension 19, 208-213.

[88] Dang, A., Zhang, Y., Liu, G., Chen, G., Song, W., Wang, B. (2006) Effects of losartan and irbesartan on serum uric acid in hypertensive patients with hyperuricaemia in Chinese population. Journal of human hypertension 20, 45-50.

[89] Li, J. P., Huo, Y., Liu, P. (2007) [Efficacy and safety of Enalapril-Folate acid tablets in lowering blood pressure and plasma homocysteine]. Beijing da xue xue bao. Yi xue ban = Journal of Peking University. Health sciences 39, 614-618.

[90] Sho, T., Xu, J. (2019) Role and mechanism of ROS scavengers in alleviating NLRP3-mediated inflammation. Biotechnology and applied biochemistry 66, 4-13.

[91] Burns, C. M., Wortmann, R. L. (2011) Gout therapeutics: new drugs for an old disease. Lancet (London, England) 377, 165-177.

[92] Gupta, G., Krishna, G., Chellappan, D. K., Gubbiyappa, K. S., Candasamy, M., Dua, K. (2014) Protective effect of pioglitazone, a PPARY agonist against acetaminophen-induced hepatotoxicity in rats. Molecular and cellular biochemistry 393, 223-228.

This article is protected by copyright. All rights reserved. 
[93] Gupta, G., Singh, R., David, S. R., Verma, R. K. (2013) Effect of R osiglitazone, a PPAR- $\gamma$ Ligand on $\mathrm{H}$ aloperidol-I nduced $\mathrm{C}$ atalepsy. CNS neuroscience \& therapeutics 19, 724-725.

[94] Lewis, A. S., Murphy, L., McCalla, C., Fleary, M., Purcell, S. (1984) Inhibition of mammalian xanthine oxidase by folate compounds and amethopterin. The Journal of biological chemistry 259, 12-15.

[95] Zhang, B. Q., Wang, G., Zhang, J. P., Hu, J. Y., Xiao, R., Lei, Z. Y., Ruan, J., Dang, Y. M., Zhang, D. X., Bian, X. W., Huang, Y. S. (2012) Protective effects of enalapril, an angiotensin-converting enzyme inhibitor, on multiple organ damage following scald injury in rats. Biotechnology and applied biochemistry 59, 307-313.

\section{Figure Ligands:}

\section{Synthesis and metabolism of Homocysteine}

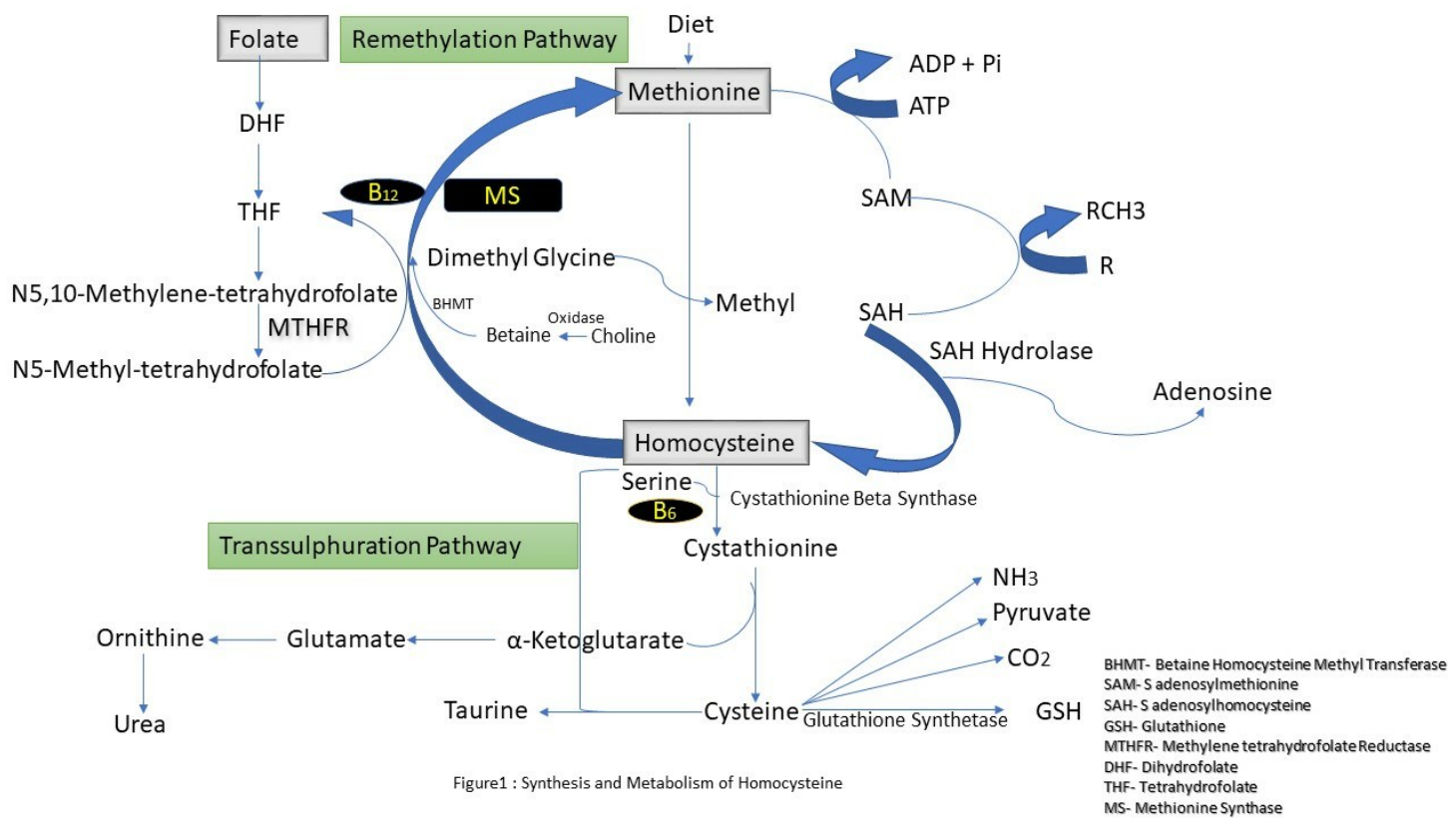

This article is protected by copyright. All rights reserved. 